\title{
Possible Involvement of Smad Signaling Pathways in Induction of Odontoblastic Properties in KN-3 Cells by Bone Morphogenetic Protein-2: A Growth Factor to Induce Dentin Regeneration
}

\author{
Ayako Washio, ${ }^{1}$ Chiaki Kitamura, ${ }^{1}$ Takahiko Morotomi, ${ }^{2}$ Masamichi Terashita, ${ }^{3}$ \\ and Tatsuji Nishihara ${ }^{4}$ \\ ${ }^{1}$ Division of Pulp Biology, Operative Dentistry, and Endodontics, Department of Cariology and Periodontology, \\ Kyushu Dental College, Kitakyushu, Japan \\ ${ }^{2}$ Section of Operative Dentistry and Endodontology, Department of Odontology, Fukuoka Dental College, Fukuoka, Japan \\ ${ }^{3}$ Division of Comprehensive Dentistry, Department of Clinical Communication and Practice, \\ Kyushu Dental College, Kitakyushu, Japan \\ ${ }^{4}$ Division of Infections and Molecular Biology, Department of Health Promotion, \\ Kyushu Dental College, Kitakyushu, Japan
}

Correspondence should be addressed to Ayako Washio, ayacchi@kyu-dent.ac.jp

Received 28 September 2011; Accepted 12 December 2011

Academic Editor: Kotaro Tanimoto

Copyright (c) 2012 Ayako Washio et al. This is an open access article distributed under the Creative Commons Attribution License, which permits unrestricted use, distribution, and reproduction in any medium, provided the original work is properly cited.

\begin{abstract}
We examined the effects of bone morphogenetic protein-2 (BMP-2) on growth, differentiation, and intracellular signaling pathways of odontoblast-like cells, KN-3 cells, to clarify molecular mechanisms of odontoblast differentiation during pulp regeneration process. After treatment with BMP-2, the cell morphology, growth, alkaline phosphatase (ALP) activity, and the activation and expression of BMP-induced intracellular signaling molecules, such as Smad1/5/8 and Smad6/7, as well as activities of dentin sialoprotein (DSP) and dentin matrix protein 1 (DMP1), were examined. BMP-2 had no effects on the morphology, growth, or ALP activity of KN-3 cells, whereas it induced the phosphorylation of Smad1/5/8 and expression of Smad6/7. BMP-2 also induced the expressions of DSP and DMP-1. Our results suggest that KN-3 cells may express an odontoblastic phenotype with the addition of BMP-2 through the activation of Smad signaling pathways.
\end{abstract}

\section{Introduction}

When dental pulp is exposed to external stimuli such as bacterial infection and following restorative procedures, a wound healing process is induced, and surviving odontoblasts and odontoblast-like cells differentiated from progenitor or stem cells form reactionary and reparative dentin to block further external stimuli [1-3]. During the regeneration process of dental pulp, similar mechanisms to form new dentin are also induced. Previously, it was demonstrated that controlled release of fibroblast growth factor-2 (FGF2) from gelatin hydrogel beads induced regeneration of dentin and pulp tissue on amputated dental pulp $[4,5]$. Furthermore, applications of bone morphogenetic proteins2 and -4 (BMP-2,-4) along with dentin powder [6] and BMP2 along with dental pulp stem cells [7] induced regeneration of dentin on amputated dental pulp. Several studies have focused on clarification of a common mechanism existing in wound healing and regeneration of dental pulp in order to overcome the limitations of present methods to preserve vital dental pulp and develop effective pulp regeneration therapies; however, the molecular mechanisms of odontoblastic cells activated by BMP-2 are not fully understood.

BMPs are known to have diverse biological functions during embryonic development $[8,9]$ and osteogenesis [10, 11]. Notably, the regulation mechanisms of Runx $2 / \mathrm{Smad}$ and other cascades controlled by BMP-2 during osteoblast and odontoblast differentiation from mesenchymal stem cells have been extensively studied [12-17]. In addition, the combination of BMP-2 with a collagen sponge was recently approved by the US Food and Drug Administration for clinical use such as oral maxillofacial surgery [18], 
while further studies have focused on development of an effective method based on available clinical data as well as to understanding the effects of BMP-2.

We previously established a proliferating pulp progenitor cell line ( $\mathrm{KN}-3$ cells) from dental papilla cells of rat incisors [19]. KN-3 cells have high levels of alkaline phosphatase (ALP) activity and expression of Runx2 and dentin sialophosphoprotein (DSPP). The addition of the medium including ascorbic acid and $\beta$-glycerophosphate induced the formation of extracellular mineralized nodules, which was suppressed by bacterial lipopolysaccharides. These findings indicated that $\mathrm{KN}-3$ cells exhibited typical odontoblastic properties [19]. To understand molecular mechanisms of the differentiation of $\mathrm{KN}-3$ cells into functional odontoblast-like cells, we examined the effects of BMP-2 on the cell growth, differentiation, and the involvement of Smads signaling pathways in the responses of KN-3 cells on BMP-2.

\section{Materials and Methods}

2.1. Cell Culture. A rat clonal dental pulp cell line with odontoblastic properties $(\mathrm{KN}-3)$ was maintained in alphamodification of Eagle's medium ( $\alpha$-MEM) (Invitrogen Life Technology, Carlsbad, CA) containing 10\% heat-inactivated fetal calf serum (FCS), $100 \mu \mathrm{g} / \mathrm{mL}$ of streptomycin, and $100 \mathrm{U} / \mathrm{mL}$ of penicillin in a humidified atmosphere of $5 \%$ $\mathrm{CO}_{2}$ at $37^{\circ} \mathrm{C}[19]$.

2.2. Morphological Analysis. $\mathrm{KN}-3$ cells $\left(3 \times 10^{4} /\right.$ well $)$ were subcultured in 6-well plates for 24 hours in $\alpha$-MEM containing $10 \%$ FCS, $100 \mu \mathrm{g} / \mathrm{mL}$ of streptomycin, and $100 \mathrm{U} / \mathrm{mL}$ of penicillin, then treated with BMP-2 $(100 \mathrm{ng} / \mathrm{mL})$ in $\alpha$ MEM containing 5\% FCS, $100 \mu \mathrm{g} / \mathrm{mL}$ of streptomycin, and $100 \mathrm{U} / \mathrm{mL}$ of penicillin in a humidified atmosphere of $5 \%$ $\mathrm{CO}_{2}$ at $37^{\circ} \mathrm{C}$. After 72 hours, the cells were observed by phase-contrast microscopy.

2.3. Cell Viability Assay. The cell proliferation reagent WST1 was used for quantitative determination of cellular proliferation (Dojindo, Kumamoto, Japan). KN-3 cells $(2 \times$ $10^{4} /$ well) were subcultured in 96-well plates for 3 hours in $\alpha$-MEM containing $10 \%$ FCS, $100 \mu \mathrm{g} / \mathrm{mL}$ of streptomycin, and $100 \mathrm{U} / \mathrm{mL}$ of penicillin, then treated with BMP-2 $(0$ $100 \mathrm{ng} / \mathrm{mL}$ ) in $\alpha$-MEM containing 5\% FCS, $100 \mu \mathrm{g} / \mathrm{mL}$ of streptomycin, and $100 \mathrm{U} / \mathrm{mL}$ of penicillin in a humidified atmosphere of $5 \% \mathrm{CO}_{2}$ at $37^{\circ} \mathrm{C}$ for 48 hours. WST-1 and 1Methoxy PMS $(10 \mu \mathrm{L} /$ well) were added and incubation was performed for 2-4 hours, after which the viability of $\mathrm{KN}$ 3 cells was analyzed by measuring optical density with a microplate reader (Model 680; Bio-Rad laboratories, Inc., Tokyo, Japan) using a test wavelength of $450 \mathrm{~nm}$.

2.4. Alkaline Phosphatase Activity. KN-3 cells $\left(1 \times 10^{4} /\right.$ well $)$ were subcultured in 96-well plates for 24 hours in $\alpha$ MEM containing $10 \%$ FCS, $100 \mu \mathrm{g} / \mathrm{mL}$ of streptomycin, and $100 \mathrm{U} / \mathrm{mL}$ of penicillin, and then treated with BMP-2 $(100 \mathrm{ng} / \mathrm{mL})$ in $\alpha$-MEM containing $0.1 \%$ FCS, $100 \mu \mathrm{g} / \mathrm{mL}$ of streptomycin, and $100 \mathrm{U} / \mathrm{mL}$ of penicillin in a humidified atmosphere of $5 \% \mathrm{CO}_{2}$ at $37^{\circ} \mathrm{C}$. After $1,3,5$, and 7 days, the cells were solubilized with $200 \mu \mathrm{L}$ of Hank's salt solution containing $0.2 \%$ Nonidet P-40 (Pierce Biotechnology, Rockford, IL) for 10 minutes at $37^{\circ} \mathrm{C}$. ALP activity of the lysate was measured using $p$-nitrophenylphosphate with the Lowry method. After 30 minutes of incubation at $37^{\circ} \mathrm{C}$, the absorbance of $p$-nitrophenylphosphate at $405 \mathrm{~nm}$ was determined by using a microplate reader, and the specific activity of ALP ( $\mu \mathrm{g} / \mu \mathrm{g}$ of protein/30 minutes) was calculated. Protein contents were measured with a DC protein assay kit (Bio-Rad Lab, Hercules, CA).

2.5. Western Blot Analysis. KN-3 cells treated with BMP-2 were washed with phosphate-buffered saline (PBS; pH 7.2) and lysed in cell lysis buffer $(50 \mathrm{mM}$ Tris- $\mathrm{HCl}$ containing $2 \%$ SDS). Protein contents were measured using a DC protein assay kit (Bio-Rad, Hercules, CA). The samples were subjected to $10 \%$ SDS-PAGE, and then transferred to polyvinylidene difluoride membranes (Millipore Corp., Billerica, MA). Nonspecific binding sites were blocked by immersing the membranes in $5 \%$ bovine serum albumin in PBS for 1 hour at room temperature, then they were incubated with the primary antibodies; rabbit antidentin sialoprotein (DSP) (Santa Cruz Biotechnology, Inc., Santa Cruz, CA, USA) and rabbit antidentin matrix protein 1 (DMP-1) (Takara Bio, Inc., Shiga, Japan). Subsequently, the membranes were incubated with anti-rabbit and antimouse IgG secondary antibodies (GE Healthcare, Little Chalfont, and Buckinghamshire, UK). Immunodetection was performed using an ECL plus Western blot detection system (GE Healthcare), according to the manufacturer's instructions. Blots were stained with Coomassie Brilliant Blue and all lanes were confirmed to contain similar amounts of protein extract.

2.6. Statistical Analysis. Statistical differences were determined using one-way ANOVA computation combined with Scheffe test for multiple comparisons. All data are expressed as the mean $\pm \mathrm{SD}$.

\section{Results}

3.1. Cell Viability, Morphology, and ALP Activity of KN-3 Cells. Figure 1 shows the effects of BMP-2 $(100 \mathrm{ng} / \mathrm{mL})$ on cell viability, morphology, and ALP activity of $\mathrm{KN}-3$ cells. The results of the WST-1 assay showed no significant differences in cell viability among several different concentrations of BMP-2 (Figure 1(a)). Also, there were no differences in the morphology of $\mathrm{KN}-3$ cells before and after confluence between the presence and absence of BMP-2 (Figure 1(b)). The ALP activity of KN-3 cells after confluence increased in a time-dependent manner, regardless of exposure to BMP-2 (Figure 1(c)).

3.2. Intracellular Responses of $\mathrm{KN}-3$ Cells. Figure 2 shows the effects of BMP-2 on the activation of Smad signaling pathways. The addition of BMP-2 $(100 \mathrm{ng} / \mathrm{mL})$ induced phosphorylation of Smad1/5/8 in KN-3 cells, which reached 


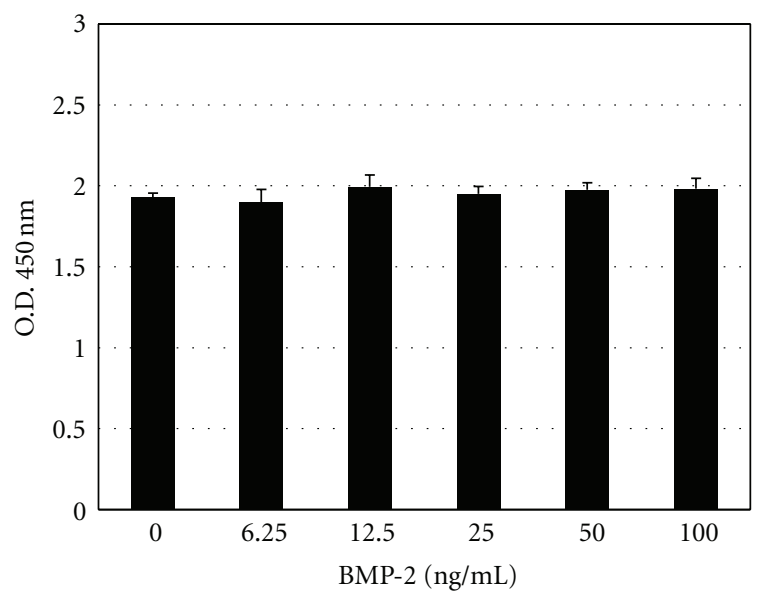

(a)

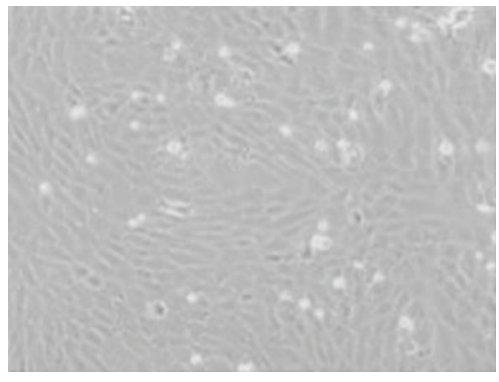

Nontreated

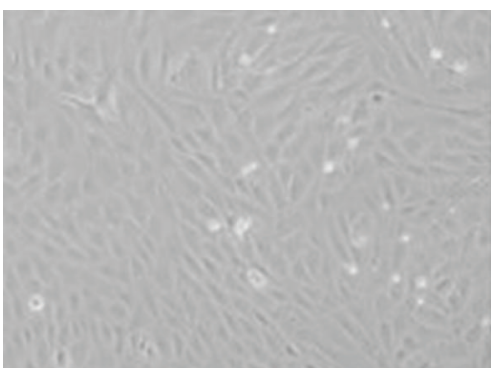

BMP-2 treated

(b)

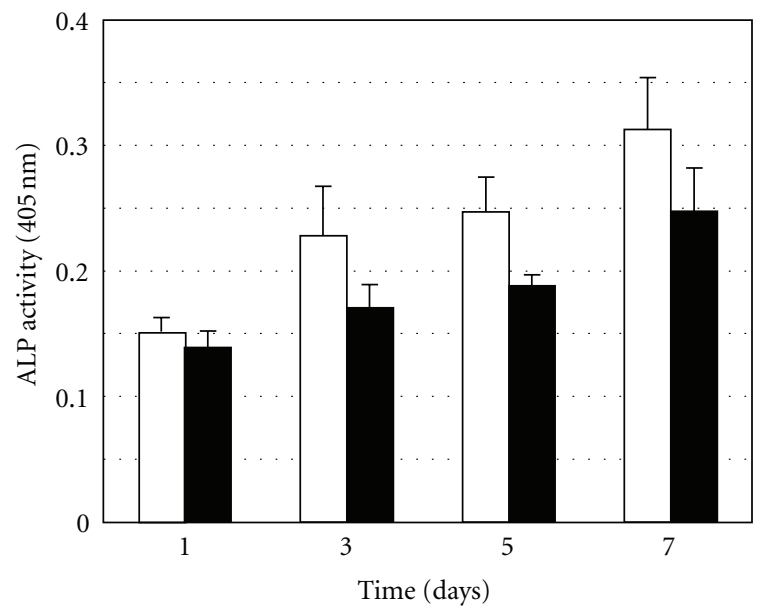

$\square 0 \mathrm{ng} / \mathrm{mL}$

- $100 \mathrm{ng} / \mathrm{mL}$

(c)

FIGURE 1: (a) Viability of KN-3 cells after exposure to BMP-2. Data are expressed as the mean \pm standard deviation of triplicate cultures. Each experiment was performed 3 times, with similar results obtained in each. (b) Phase-contrast microphotographs of KN-3 cells treated with BMP-2 (100 ng/mL) for 72 hours. (c) Alkaline phosphatase activity of KN-3 cells treated with BMP-2 (100 ng/mL). BMP-2 was replaced with fresh medium every 3 days.

a maximum level within 30 minutes (Figure 2(a)). Also, the BMP-2-induced phosphorylation of Smad1/5/8 increased in a dose-dependent manner, and the maximum in the phosphorylation was at $100 \mathrm{ng} / \mathrm{mL}$ of BMP-2 (Figure 2(b)).
The expressions of Smad6 and 7 appeared to increase at 24 hours and reached a maximum level within 72 hours after the addition of BMP-2 $(100 \mathrm{ng} / \mathrm{mL})$ and then continued throughout the culture period (Figure 2(c)). 


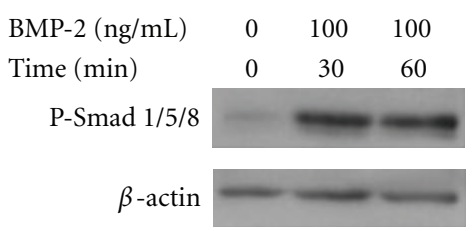

(a)

BMP-2 (100 ng/mL)

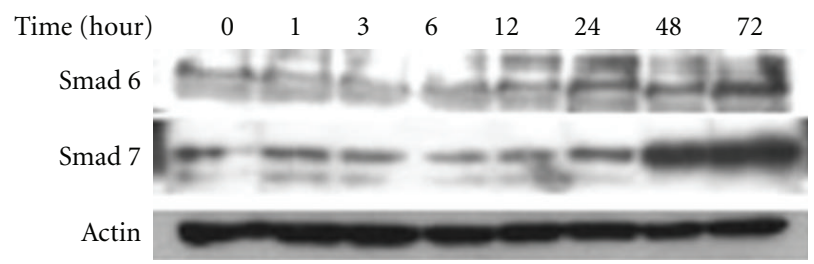

(c)

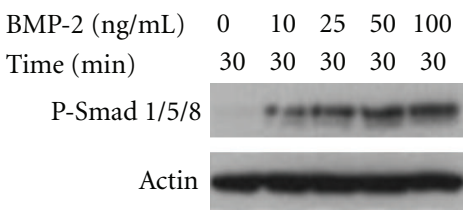

(b)

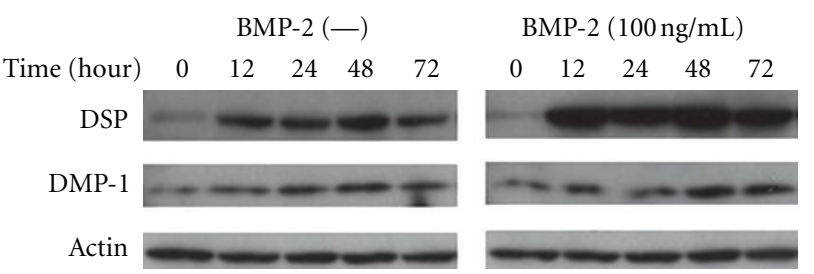

(d)

Figure 2: Western blot analysis of (a) and (b) phosphorylated Smad1/5/8, (c) inhibitory Smad6/7, and (d) DSP and DMP-1 extracted from $\mathrm{KN}-3$ cells after treatment with BMP-2.

The expression of DSP and DMP-1, markers of odontoblast differentiation, were increased at 12 and 48 hours, respectively, following the addition of BMP-2 $(100 \mathrm{ng} / \mathrm{mL})$, the expression of DSP were increased throughout the culture period, but that of DMP-1 had been on the increase, but not significantly (Figure 2(d)).

\section{Discussion}

A number of studies have used primary dental pulp cells, existing pulp cell lines, and a few odontoblastic cells lines, and characterized their properties to elucidate tooth development, responses of dental pulp to external stimuli, as well as therapeutic approaches for the dentin-pulp complex. Previously, we established KN-3 cells from dental pulp and found that the cells had odontoblastic properties. In the present study, we examined the effects of BMP-2, the most bioactive molecules to induce osteoblast and odontoblast differentiation, on $\mathrm{KN}-3$ cells in vitro in order to clarify further characteristics of $\mathrm{KN}-3$ cells as odontoblastic-like cells. BMP-2 had no effects on cell growth, morphology, and ALP activity of KN-3 cells. Previously, we reported that KN-3 cells are able to form calcified nodules. It was also suggested that the outgrowth of odontoblastic process was induced by FGF-2 to a much greater degree than BMP-2, and that base membrane components such as laminin also had effects on the outgrowth of odontoblastic process [20, 21]. Furthermore, it was shown that MC3T3-E1 cells, osteoblastic cell line, differentiated into odontoblasts without upregulation of ALP activity [22], suggesting that an increase in ALP activity is not necessary for odontoblast differentiation. The present results support the notion that BMP-2 is not necessary for morphological change or activation of ALP in the process of differentiation of odontoblast-like cells.

In contrast, the present results revealed that BMP-2 induced activation of intracellular signaling pathways in $\mathrm{KN}$ 3 cells, as we found phosphorylation of $S \operatorname{mad} 1 / 5 / 8$, and upregulation of Smad6 and 7 in BMP-2-treated KN-3 cells.
It is well known that the members of TGF- $\beta$ including BMPs activate Smad proteins are intracellular signaling molecules, and that the Smad pathway is one of important signaling pathways in signal interpretation from the ECM during osteogenesis/dentinogenesis. There are 3 types of Smads: receptor regulated (R-Smads), common mediator (Co-Smads), and inhibitory (I-Smads) [23]. Following the phosphorylation R-Smads (Smad1, 5, and 8) by BMPs, heteromeric complexes are formed with Co-Smad (Smad4) and translocate to the nucleus where they regulate the transcription of target genes together with other nuclear cofactors. In the present study, we clearly detected that BMP2 -induced phosphorylation of Smad1/5/8 in KN-3 cells, as well as upregulation of Smad6 and 7. I-Smads (Smad6 and 7) provide feedback inhibition of BMP-receptor activation by blocking continued R-Smad phosphorylation by BMP receptors, suggesting that upregulation of I-Smads may be essential to limit BMP signaling for proper odontoblastic differentiation of $\mathrm{KN}-3$ cells. Taken together, the present results are the first to demonstrate that $\mathrm{KN}-3$ cells respond to BMP-2 signaling via activation of Smad signaling pathways.

We also examined whether BMP-2 has effects on the expressions of odontoblast specific molecules in KN-3 cells and found that those of DSP and DMP-1 were induced by BMP-2 in a time-dependent manner. DSP is a noncollagenous dentin matrix protein that is transcripted from the dentin sialophosphoprotein (DSPP) gene and known as an odontoblast-specific protein [24-27]. The previous study revealed that KN-3 cells cultured for 72 hours showed high expression level of DSPP [19], indicating that KN-3 cells are precursor cells, which have abilities to differentiate into odontoblast-like cells. DSP increase in BMP-2-untreated cells in the present study was resulted from the properties of $\mathrm{KN}-3$ cells, and the enhanced expression of DSP on BMP-2-treated KN-3 cells indicates the upregulation of odontoblastic differentiation. DMP-1 is a noncollagenous protein expressed in mineralized tissues [24-26, 28]. Various lines of evidence indicate that DSP is induced in the 


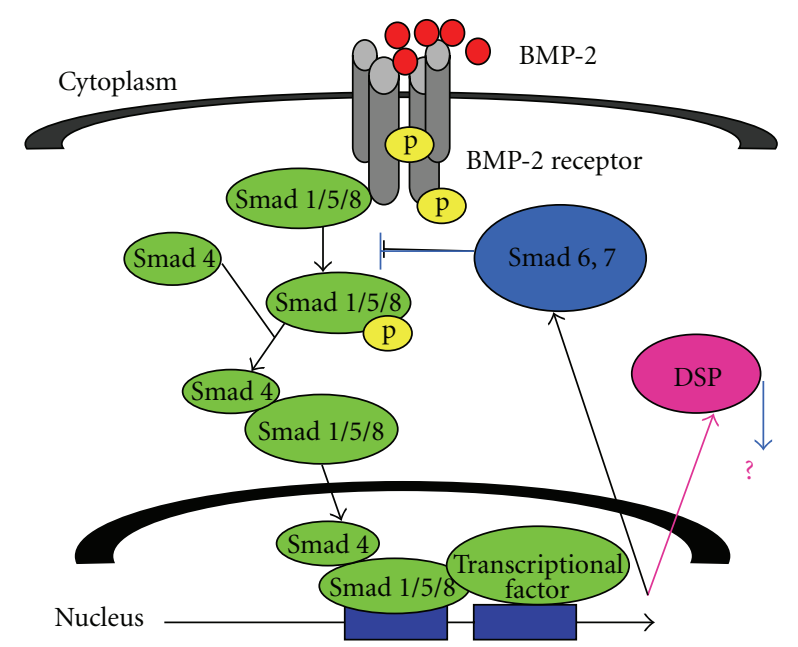

FIgURE 3: Proposed schema of Smad signaling pathways in KN-3 cells.

early stage of odontoblast differentiation, whereas DMP-1 is induced in the late stage and tightly bound to the mineral phase of dentin. In the present study, effects of BMP-2 on the early stage of $\mathrm{KN}-3$ cell differentiation were analyzed, resulting in no significant difference in DMP-1 expression between BMP-2-treated and nontreated cells and the less expression of DMP-1 than that of DSP in BMP-2-treated cells.

Our results indicate that BMP-2 plays critical roles in induction of the odontoblast properties of $\mathrm{KN}-3$ cells via activation of Smad signaling pathways. In previous studies [29], it was indicated that BMP-2 mediates DSPP expression and odontoblast differentiation and Smad signaling pathway plays a crucial part in the regulation of Dspp expression through the action of Smads, Dlx5, Runx2, and Msx2, suggesting that the expressions of DSP and DMP1 in KN3 cells may be linked to the Smad pathway (Figure 3). We are continuing research to clarify the direct regulation of DSP and DMP-1, as well as mineralized nodule formation in the later stage of KN-3 cells differentiation, by BMP-2-Smad signaling pathway. Our results also show that KN-3 cells with odontoblastic properties are useful to clarify molecular mechanisms of odontoblasts against external stimuli such as growth factors, in order to develop appropriate regeneration therapy for the dentin-pulp complex.

\section{Acknowledgment}

This research was supported by a Grant-in-Aid for Scientific Research (20592231, Kitamura) from the Ministry of Education, Science, and Culture of Japan, Tokyo, Japan.

\section{References}

[1] H. A. Makkawy, S. Koka, M. T. Lavin, and N. O. Ewoldsen, "Cytotoxicity of root perforation repair materials," Journal of Endodontics, vol. 24, no. 7, pp. 477-479, 1998.

[2] A. Al-Daafas and S. Al-Nazhan, "Histological evaluation of contaminated furcal perforation in dogs' teeth repaired by
MTA with or without internal matrix," Oral Surgery, Oral Medicine, Oral Pathology, Oral Radiology and Endodontology, vol. 103, no. 3, pp. e92-e99, 2007.

[3] C. M. Bramante and A. Berbert, "Influence of time of calcium hydroxide iodoform paste replacement in the treatment of root perforations," Brazilian Dental Journal, vol. 5, no. 1, pp. 45-51, 1994.

[4] N. Kikuchi, C. Kitamura, T. Morotomi et al., "Formation of dentin-like particles in dentin defects above exposed pulp by controlled release of fibroblast growth factor 2 from gelatin hydrogels," Journal of Endodontics, vol. 33, no. 10, pp. 11981202, 2007.

[5] H. Ishimatsu, C. Kitamura, T. Morotomi et al., "Formation of dentinal bridge on surface of regenerated dental pulp in dentin defects by controlled release of fibroblast growth factor- 2 from gelatin hydrogels," Journal of Endodontics, vol. 35, no. 6, pp. 858-865, 2009.

[6] M. Nakashima, "Induction of dentin formation on canine amputated pulp by recombinant human bone morphogenetic proteins (BMP)-2 and-4," Journal of Dental Research, vol. 73, no. 9, pp. 1515-1522, 1994.

[7] K. Iohara, M. Nakashima, M. Ito, M. Ishikawa, A. Nakasima, and A. Akamine, "Dentin regeneration by dental pulp stem cell therapy with recombinant human bone morphogenetic protein 2," Journal of Dental Research, vol. 83, no. 8, pp. 590$595,2004$.

[8] B. L. M. Hogan, "Bone morphogenetic proteins: multifunctional regulators of vertebrate development," Genes and Development, vol. 10, no. 13, pp. 1580-1594, 1996.

[9] X. B. Wu, Y. Li, A. Schneider et al., "Impaired osteoblastic differentiation, reduced bone formation, and severe osteoporosis in noggin-overexpressing mice," Journal of Clinical Investigation, vol. 112, no. 6, pp. 924-934, 2003.

[10] J. M. Wozney and V. Rosen, "Bone morphogenetic protein and bone morphogenetic protein gene family in bone formation and repair," Clinical Orthopaedics and Related Research, no. 346, pp. 26-37, 1998.

[11] D. Chen, M. Zhao, and G. R. Mundy, "Bone morphogenetic proteins," Growth Factors, vol. 22, no. 4, pp. 233-241, 2004.

[12] R. Venezian, B. J. Shenker, S. Datar, and P. S. Leboy, "Modulation of chondrocyte proliferation by ascorbic acid and BMP-2," Journal of Cellular Physiology, vol. 174, no. 3, pp. 331-341, 1998.

[13] F. de Luca, K. M. Barnes, J. A. Uyeda et al., "Regulation of growth plate chondrogenesis by bone morphogenetic protein2," Endocrinology, vol. 142, no. 1, pp. 430-436, 2001.

[14] K. S. Lee, H. J. Kim, Q. L. Li et al., "Runx2 is a common target of transforming growth factor $\beta 1$ and bone morphogenetic protein 2 , and cooperation between Runx 2 and Smad5 induces osteoblast-specific gene expression in the pluripotent mesenchymal precursor cell line C2C12," Molecular and Cellular Biology, vol. 20, no. 23, pp. 8783-8792, 2000.

[15] C. Banerjee, A. Javed, J. Y. Choi et al., "Differential regulation of the two principal Runx2/Cbfa1 N-terminal isoforms in response to bone morphogenetic protein-2 during development of the osteoblast phenotype," Endocrinology, vol. 142, no. 9, pp. 4026-4039, 2001.

[16] M. Zhao, G. Xiao, J. E. Berry, R. T. Franceschi, A. Reddi, and M. J. Somerman, "Bone morphogenetic protein 2 induces dental follicle cells to differentiate toward a cementoblast/osteoblast phenotype," Journal of Bone and Mineral Research, vol. 17, no. 8, pp. 1441-1451, 2002.

[17] E. Balint, D. Lapointe, H. Drissi et al., "Phenotype discovery by gene expression profiling: mapping of biological processes 
linked to BMP-2-mediated osteoblast differentiation," Journal of Cellular Biochemistry, vol. 89, no. 2, pp. 401-426, 2003.

[18] W. F. McKay, S. M. Peckham, and J. M. Badura, "A comprehensive clinical review of recombinant human bone morphogenetic protein-2 (INFUSE bone graft)," International Orthopaedics, vol. 31, no. 6, pp. 729-734, 2007.

[19] K. Nomiyama, C. Kitamura, T. Tsujisawa et al., "Effects of lipopolysaccharide on newly established rat dental pulpderived cell line with odontoblastic properties," Journal of Endodontics, vol. 33, no. 10, pp. 1187-1191, 2007.

[20] F. J. Unda, A. Martín, E. Hilario, C. Bègue-Kirn, J. V. Ruch, and J. Aréchaga, "Dissection of the odontoblast differentiation process in vitro by a combination of FGF1, FGF2, and TGF $\beta 1$," Developmental Dynamics, vol. 218, no. 3, pp. 480-489, 2000.

[21] K. Yuasa, S. Fukumoto, Y. Kamasaki et al., "Laminin $\alpha 2$ is essential for odontoblast differentiation regulating dentin sialoprotein expression," Journal of Biological Chemistry, vol. 279, no. 11, pp. 10286-10292, 2004.

[22] T. Katagiri, T. Lee, H. Takeshima, T. Suda, H. Tanaka, and S. Omura, "Transforming growth factor- $\beta$ modulates proliferation and differentiation of mouse clonal osteoblastic MC3T3-E1 cells depending on their maturation stages," Bone and Mineral, vol. 11, no. 3, pp. 285-293, 1990.

[23] S. Souchelnytskyi, A. Moustakas, and C. H. Heldin, “TGF- $\beta$ signaling from a three-dimensional perspective: insight into selection of partners," Trends in Cell Biology, vol. 12, no. 7, pp. 304-307, 2002.

[24] W. T. Butler and H. Ritchie, "The nature and functional significance of dentin extracellular matrix proteins," International Journal of Developmental Biology, vol. 39, no. 1, pp. 169-179, 1995.

[25] J. Hao, B. Zou, K. Narayanan, and A. George, "Differential expression patterns of the dentin matrix proteins during mineralized tissue formation," Bone, vol. 34, no. 6, pp. 921932, 2004.

[26] W. T. Butler, "Dentin matrix proteins," European Journal of Oral Sciences, vol. 106, no. 1, pp. 204-210, 1998.

[27] T. Sreenath, T. Thyagarajan, B. Hall et al., "Dentin sialophosphoprotein knockout mouse teeth display widened predentin zone and develop defective dentin mineralization similar to human dentinogenesis imperfecta type III," Journal of Biological Chemistry, vol. 278, no. 27, pp. 24874-24880, 2003.

[28] A. George, B. Sabsay, P. A. L. Simonian, and A. Veis, "Characterization of a novel dentin matrix acidic phosphoprotein. Implications for induction of biomineralization," Journal of Biological Chemistry, vol. 268, no. 17, pp. 12624-12630, 1993.

[29] S. Chen, J. Gluhak-Heinrich, M. Martinez et al., "Bone morphogenetic protein 2 mediates dentin sialophosphoprotein expression and odontoblast differentiation via NF-Y signaling," Journal of Biological Chemistry, vol. 283, no. 28, pp. 19359-19370, 2008. 


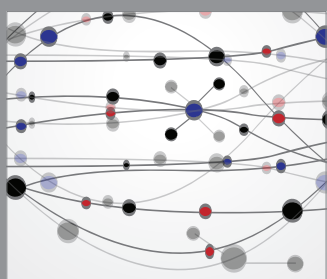

The Scientific World Journal
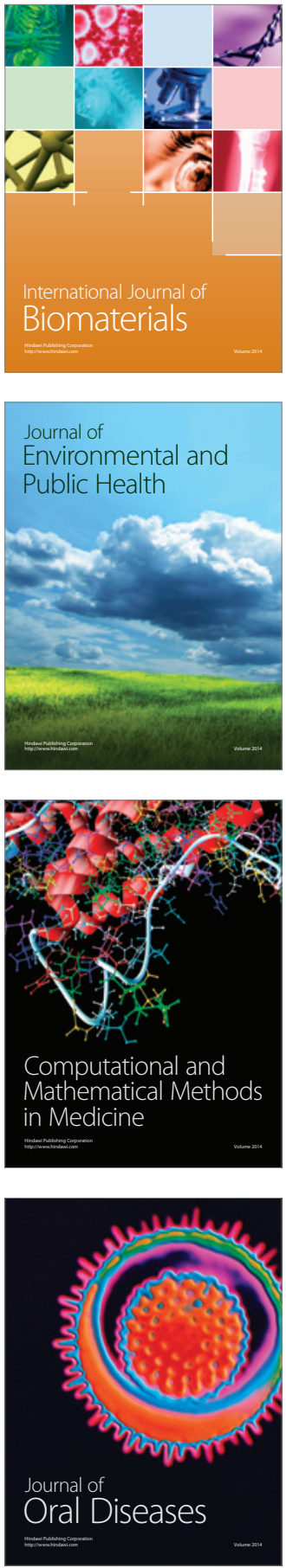
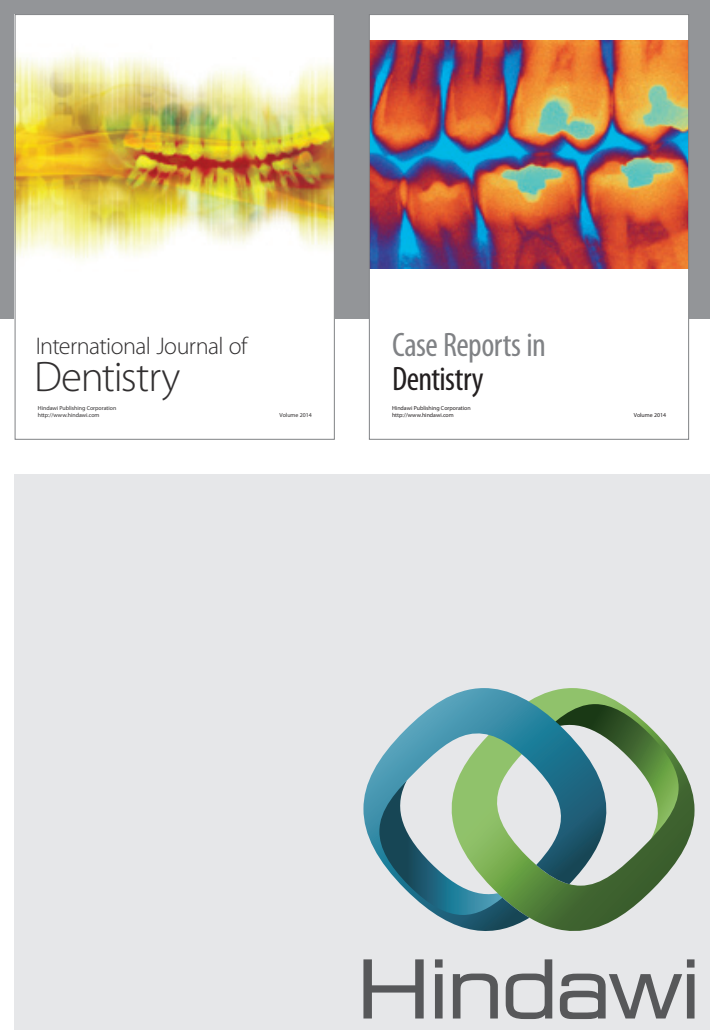

Submit your manuscripts at

http://www.hindawi.com
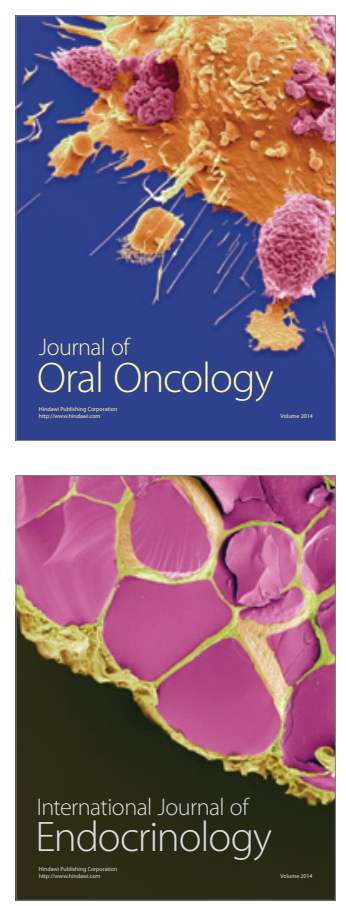
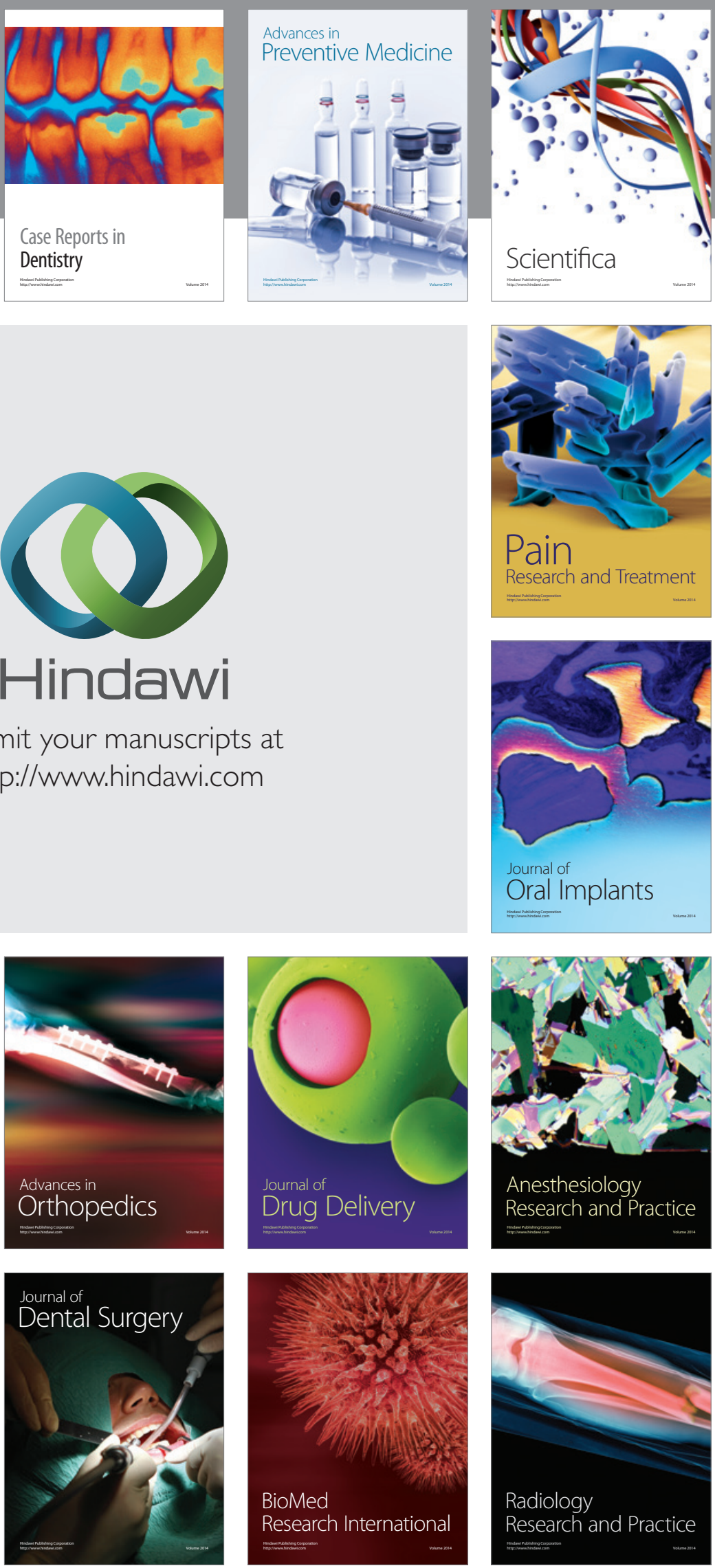